\title{
Tracing field hybridization in Ryegrass species using microsatellite and morphological markers
}

\author{
Eimear RYAN ${ }^{1}$, Ewen MULLINS ${ }^{2}$, James BURKE ${ }^{2}$, Martin DOWNES ${ }^{1}$ and Conor MEADE ${ }^{1 *}$ \\ ${ }^{1}$ Molecular Ecology Laboratory, Institute of Bioengineering and Agroecology, National University of Ireland, Maynooth, Co. Kildare, Ireland \\ ${ }^{2}$ Teagasc Crop Research Centre, Oak Park, Carlow, Co. Carlow, Ireland
}

\begin{abstract}
We have assessed the utility of morphological and microsatellite markers for tracing field hybridization between Lolium multiflorum and Lolium perenne in cereal-enclosed gene flow plots. The presence of awns on the inflorescence of $F_{1}$ hybrids was found to be a reliable, but underscoring, indicator of $L$. multiflorum paternity in L. perenne derived seed as determined by inheritance of species-specific alleles at the microsatellite locus ' $\mathrm{H} 01 \mathrm{H}^{06}$ ' in these progeny. A positive correlation was evident in the experimental treatment between the number of pollen donor plants in a given plot and the frequency of hybrid $F_{1}$ seed harvested from pollen receptor plants in that plot. These experiments have established the utility of naturally occurring heritable markers for the measurement of gene flow rates in field Ryegrass populations, with particular significance for risk assessment modeling of potential gene flow from transgenic grass cultivars.
\end{abstract}

Keywords: Lolium perenne / Lolium multiflorum / pollen flow / gene flow / molecular markers / risk assessment

\section{INTRODUCTION}

Forage and turf grasses are of major economic importance in temperate farming regions and consequently are the focus of significant genetic improvement efforts worldwide, in particular for the optimization of disease resistance and growth and nutritional characteristics (principally in Lolium, Poa, Festuca and Agrostis species). Increasingly this effort involves the use of genetic modification (GM) (presentations at the IGC, 2005; ISB, 2003; Sprangenberg et al., 1998). In Ireland the dominant forage grasses are perennial and Italian Ryegrass (Lolium perenne L. and L. multiflorum L., respectively), and the advent of suitable GM cultivars for deployment in Irish agroecosystems presents significant gene flow and co-existence questions. Ryegrass pastures, meadows and silage fields cover some $92 \%$ of Ireland's agricultural land, and form the basis for the dairy and meat industries and much of the rural economy (Meade and Mullins, 2005). A significant portion of this land is managed by extensive grazing, giving rise to species-rich grasslands of considerable ecological and conservation value.
Lolium species are a particular concern for pollenmediated gene flow because they are obligate outcrossers and readily form hybrids both with each other and with several Festuca species (Hubbard, 1984; Webb et al., 1996). Significant pollen flow from Lolium perenne plots has been recorded by Giddings et al. (1997), and developed into a landscape gene flow model by Giddings (2000). While this latter model did not incorporate the measurement of actual gene flow patterns as evidenced by pollination/hybridization events, this more precise kind of data has been generated in a landscape-level experiment on gene flow from a herbicide tolerant Agrostis stolonifera cultivar plot in the United States (Watrud et al., 2004). All three studies point to the extensive potential for gene flow from GM cultivar plots to surrounding receptive populations.

Considering the ubiquity of pollen flow from grass swards and with a view to building a longer-term geneflow modeling approach for Lolium perenne and $L$. multiflorum in the Irish agroenvironment (Flannery et al., 2005), we have set out to develop a method for measuring

\footnotetext{
* Corresponding author: conor.v.meade@nuim.ie
} 


\section{E. Ryan et al.}

pollen-mediated gene flow in field situations using heritable molecular and morphological markers. The results presented here stem from a proof-of-concept study on the efficacy of this method for completing a large-scale gene flow field trial using $L$. multiflorum as a pollen source and L. perenne as a pollen sink.

Morphological characteristics provide a quick and cost effective tool of analyzing large numbers of samples in direct gene flow experiments, and have been used in many gene flow studies, sometimes as the sole markers for estimating the rate of gene flow (e.g. Halsey et al., 2005). However, as morphological traits may be under polygenic control, and so liable to display incomplete dominance in a heritability study, we have opted to use microsatellite markers as an additional, more definitive, means for establishing paternity in $\mathrm{F}_{1}$ progeny produced in field gene flow trials. Microsatellite markers are highly suited to direct measurement of gene flow (Boys et al., 2005; Desplanque et al., 1999; Dow and Ashey, 1998; Jarne and Lagoda, 1996), particularly where alleles of different sizes occur in closely related (but reproductively isolated) species.

As a preliminary step towards carrying out large scale field trials at the Teagasc Crop Research Centre, Oak Park, Carlow, we have set out to (i) identify a microsatellite locus/loci that can differentiate between $L$. perenne Aberdart and L. multiflorum Trajan paternity in L. perenne $\mathrm{F}_{1}$ seed; (ii) carry out a pilot experiment to assess whether this paternity is traceable in a field scenario; and (iii) determine the extent to which two selected morphological traits can be used to accurately measure the true hybridization rate evident from the microsatellite data.

\section{RESULTS}

Field hybridization between L. multiforum Trajan, as pollen donor, and L. perenne Aberdart, as pollen receptor, was successfully traced using a combination of speciesspecific alleles at a microsatellite locus $\mathrm{H} 01 \mathrm{H} 06$, and paternal inheritance of awned inflorescences. The frequency of hybrids in $F_{1}$ progeny was positively correlated with the number of pollen donor plants in individual plots, however the spatial distribution of hybrids in the $12 \times 12 \mathrm{~m}$ plots was not correlated with prevailing wind patterns during the flowering period.

Screening of 16 sampled Lolium-specific microsatellite loci revealed that several displayed polymorphism across the initial sample set of $10 \mathrm{~L}$. multiflorum Trajan and 10 L. perenne Aberdart plants (Tab. 1), however fixation of species-specific alleles was clear only at locus H01 H06, with a clear size difference between the alleles evident in Trajan compared to Aberdart (Fig. 1). The presence versus absence of awns in the inflorescence (Fig. 2) proved to be a more reliable marker of $L$. multiflorum paternity in L. perenne maternal progeny than the rolled versus folded shoot habit (Fig. 3).

Table 2 and Figure 4 detail the occurrence and distribution of hybrid progeny in the experimental plots, as recorded by the presence in $\mathrm{F}_{1}$ progeny of the discriminating microsatellite alleles at locus $\mathrm{H} 01 \mathrm{H} 06$ and the presence/absence of awns and rolled shoots. Scoring for the microsatellite $\mathrm{H} 01 \mathrm{H} 06$ locus recorded 25, 11 and $0 \%$ hybrids amongst the $L$. perenne sink progeny in the 48, 24 and 0 L. multiflorum plots, respectively. Scoring for the presence of awns in the progeny set recorded 16, 6 and $0 \%$ hybrids in the same set, while scoring for rolled shoots recorded 29,11 , and $4 \%$ hybrids in the $L$. perenne $\mathrm{F}_{1}$ progeny.

A significant difference between the observed hybrid numbers in the 3 experimental plots was recorded in a Chisquare test, and there was also a significant correlation between the number of source plants and the number of hybrids in each of the plots (Tab. 3). A Spearman rankorder test found no significant correlation between the predominant wind direction during flowering, which was from the south and south-west, and the observed spatial patterns of hybridization (Tab. 3, Fig. 4).

\section{DISCUSSION}

The microsatellite locus H01 H06 (repeat motif $[\mathrm{CA}]_{9}$, Jones et al., 2001) has been identified as a molecular marker that can trace hybridization between $L$. perenne Aberdart $\times$ L. multiflorum Trajan (Fig. 1). From Table 2 and Figure 4 it can be seen that the rates of hybridization in each plot recorded using H01 H06 are positively correlated with the number of source plot plants present. It is also evident from the control site with no pollen source plants that the winter oats surrounding the pilot plots appear to have excluded pollen from outside the experimental site, and prevented pollen flow between plots within the site, as well as buffering against predominant wind movements over the duration of the flowering period.

The number of hybrids identified using morphological traits differed from the number identified using the microsatellite marker. In the case of the elongated awns, the number of hybrids recorded was lower than for the microsatellite total, and each plant that carried awns also scored positively for the L. multiflorum microsatellite marker. The rolled leaf shoots character proved more unreliable, recording more putative hybrids than the 
Tracing Ryegrass hybridization using microsatellite and morphological markers

Table 1. Microsatellite loci screened for species-specific alleles in L. perenne Aberdart and L. multiflorum Trajan.

\begin{tabular}{|c|c|c|c|c|}
\hline $\begin{array}{l}\text { Locus name } \\
\text { (source)* }\end{array}$ & $\begin{array}{l}\text { Primer sequence } \\
\qquad\left(5^{\prime}-3^{\prime}\right)\end{array}$ & Repeat motif & $\begin{array}{l}\text { Total number } \\
\text { of alleles }\end{array}$ & $\begin{array}{l}\text { Species-specific } \\
\text { alleles }\end{array}$ \\
\hline $\mathrm{H} 01 \mathrm{~A} 02^{1}$ & $\begin{array}{lc}\mathrm{F} & \text { AAAGACCGCATACGAAGT } \\
\mathrm{R} & \text { AACCAAAGCCTCAAGACA }\end{array}$ & $(\mathrm{CA})_{27}$ & 5 & $\mathrm{~N}$ \\
\hline $\mathrm{H} 01 \mathrm{~A} 07^{1}$ & $\begin{array}{ll}\mathrm{F} & \text { TGGAGGGCTCGTGGAGAAGT } \\
\mathrm{R} & \text { CGGTTCCCACGCCTTGC }\end{array}$ & $(\mathrm{GT})_{9}$ & 3 & $\mathrm{~N}$ \\
\hline $\mathrm{H} 01 \mathrm{~A} 10^{1}$ & $\begin{array}{ll}\mathrm{F} & \text { GAGGCACCGGCCATGGAG } \\
\mathrm{R} & \text { AGGACGAGCCACTCACTTG }\end{array}$ & $(\mathrm{CTT})_{20}$ & 4 & $\mathrm{~N}$ \\
\hline H01 D09 ${ }^{1}$ & $\begin{array}{l}\text { F CAAGTGCCACCATAGATACAA } \\
\text { R CGTGAAGATCACTATAAACACGA }\end{array}$ & $(\mathrm{AG})_{8}$ & 1 & $\mathrm{~N}$ \\
\hline H01 E10 1 & $\begin{array}{ll}\text { F } & \text { CGCAGCTTAATTTAGTC } \\
\text { R } & \text { GCTTTGAGTATGTAAAGTT }\end{array}$ & $(\mathrm{CA})_{10}$ & 4 & $\mathrm{~N}$ \\
\hline $\mathrm{H} 01 \mathrm{~F} 02^{1}$ & $\begin{array}{ll}\mathrm{F} & \text { TCTGTGGGTCCTTCTGGAT } \\
\mathrm{R} & \text { TCGGGTGATGATGTTGACTT }\end{array}$ & $(\mathrm{TCGC})_{6}$ & 1 & $\mathrm{~N}$ \\
\hline H01 H06 ${ }^{1}$ & $\begin{array}{l}\text { F ATTGACTGGCTTCCGTGTT } \\
\text { R CGCGATTGCAGATTCTTG }\end{array}$ & $(\mathrm{CA})_{9}$ & 4 & $\mathrm{Y}$ \\
\hline $\mathrm{H} 02 \mathrm{C}_{1} 1^{1}$ & $\begin{array}{ll}\mathrm{F} & \text { TGGAATAACGATGAAAAG } \\
\mathrm{R} & \text { CATCACGAATTAACAAGAG }\end{array}$ & $(\mathrm{CA})_{4} \mathrm{TA}(\mathrm{CA})_{4}$ & 7 & $\mathrm{~N}$ \\
\hline $\mathrm{K} 01 \mathrm{~A} 03^{2}$ & $\begin{array}{ll}\mathrm{F} & \text { GGACGAACTGCCGAGACA } \\
\mathrm{R} & \text { CGGGCATGGTGAGAAGGA }\end{array}$ & $(\mathrm{CTT})_{7}$ & 1 & $\mathrm{~N}$ \\
\hline $\mathrm{K} 01 \mathrm{~A} 11^{2}$ & $\begin{array}{ll}\mathrm{F} & \text { CGGCCACCCTTGATAGAG } \\
\mathrm{R} & \text { TCGTCAAGGATCCGGAGA }\end{array}$ & $(\mathrm{CA})_{21}$ & 4 & $\mathrm{~N}$ \\
\hline M4-213 & $\begin{array}{l}\mathrm{F} \text { CACCTCCCGCTGCATGGCATGT } \\
\mathrm{R} \text { TACAACGACATGTCAAGG }\end{array}$ & $(\mathrm{GT})_{8} \mathrm{AGGT}$ & 3 & $\mathrm{~N}$ \\
\hline M15-185 & $\begin{array}{ll}\mathrm{F} & \text { GGTCTGGTAGACATGCCTAC } \\
\mathrm{R} & \text { TACCAGCACAGGCAGGTTC }\end{array}$ & $(\mathrm{GA})_{5}$ TTAGAGG(GA) 17 & 9 & $\mathrm{~N}$ \\
\hline M16-B ${ }^{2}$ & $\begin{array}{ll}\mathrm{F} & \text { TGCTGTGGCTCTTGTGAC } \\
\mathrm{R} & \text { AGCCGAGGCTCAGCTCGA }\end{array}$ & $(\mathrm{GA})_{3} \mathrm{G}(\mathrm{GA})_{18} \mathrm{GG}(\mathrm{GA})_{7}$ & 10 & $\mathrm{~N}$ \\
\hline M4- $136^{2}$ & $\begin{array}{ll}\mathrm{F} & \text { AGAGACCATCACCAAGCC } \\
\mathrm{R} & \text { TCTGGAAGAAGATTTCCTTG }\end{array}$ & $\operatorname{GATT}(\mathrm{GA})_{12} \mathrm{GT}(\mathrm{GA})_{15}$ & 9 & $\mathrm{~N}$ \\
\hline M2- $148^{2}$ & $\begin{array}{ll}\mathrm{F} & \text { GCAACTTCTATCGAGTTG } \\
\mathrm{R} & \text { GAGGCTCGATCTTCACGGA }\end{array}$ & $\begin{array}{l}(\mathrm{GT})_{9} \\
(\mathrm{GA})_{9}\end{array}$ & 4 & $\mathrm{~N}$ \\
\hline $\mathrm{M} 12-52^{2}$ & $\begin{array}{ll}\mathrm{F} & \text { CTACAATGCATTCGTGCA } \\
\mathrm{R} & \text { TAGAGGCCACCCGCGCCCT }\end{array}$ & $(\mathrm{GA})_{9}$ & 3 & $\mathrm{~N}$ \\
\hline
\end{tabular}

Jones et al., 2001.

${ }^{2}$ Kubik et al., 1999.

microsatellite marker in all three plots. Significantly, several of the plants showing what appeared to be a rolled shoot did not score positively for the L. multiflorum microsatellite marker, while several others that did score positively for this microsatellite marker did not show the rolled shoot habit.

From these data it is evident that hybridization rates in a large grass gene-flow field experiment can be measured using a combination of these cultivars and the H01 H06 marker, and that interspecific hybridization between $L$. multiflorum pollen donors and L. perenne pollen receptors is possible even in the presence of pollen competition from adjacent $L$. perenne plants. In terms of larger scale experiments, because it is not feasible to analyze all $\mathrm{F}_{1}$ progeny using PCR (the total $\mathrm{F}_{1}$ seed in a large trial may number 10 or 20000 ) it would appear that hybrid progeny can be scored using the elongated awns character (but not the rolled shoot character), provided a more accurate estimate of under-recording of hybrids can be generated. In terms of the broader GMO biosafety research effort, these results provide further evidence that field assessment of gene flow patterns within and between wind-pollinated species need not require the deployment of GM varieties for the measurement of actual gene flow patterns. 


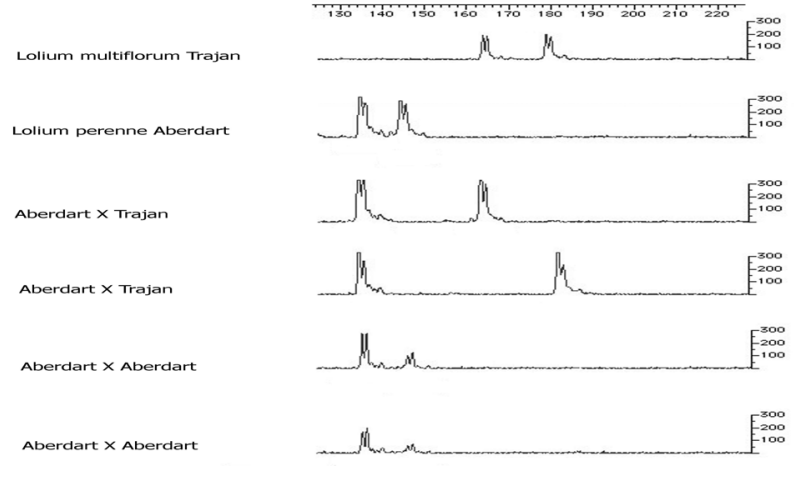

Figure 1. Sample microsatellite allele profiles in Lolium multiflorum Trajan, Lolium perenne Aberdart and hybrids between these two species as recorded at the H01 H06 locus. Horizontal scale indicates the size of fragments in nucleotide base pairs (bp). Vertical scale indicates fluorescence level of fragments, a general indicator of fragment quantity.

While the results presented here relate to a gene-flow proof of concept study only, and we firmly believe that all GM crop risk assessment should ultimately focus on the ecological impact of a novel trait rather than the breeding technology that facilitated it (Meade and Mullins, 2005; Tiedje et al., 1989), there is an underlying need for this kind of research that perhaps has been overlooked by McHughen (2006). The use of pre-existing non-GM cultivars in gene-flow studies allows us to estimate parameters for the various components that make up broader composite gene flow models such as GENESYS (Colbach et al., 2001) and the Gene Flow Index (GFI) model of Flannery et al. (2005). This is particularly true where high levels of variance in natural dispersal and recruitment patterns for particular GFI components (such as gene flow between wild populations and seedling recruitment from harvest spillage) imply unacceptable risks for the experimental release of GM cultivars. Given the importance and extent of flowering grasslands in Ireland, the experimental release of GM grass cultivars,
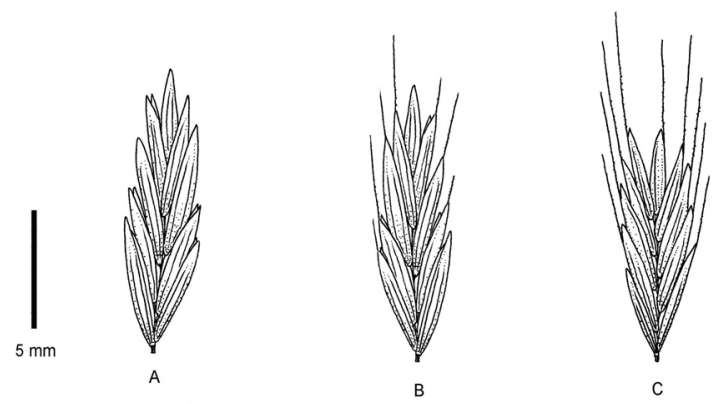

Figure 2. Inheritance of inflorescence characteristics in L. perenne $\times$ multiflorum hybrid crosses. A. Inflorescence structure of Lolium perenne. B. Inflorescence structure of hybrid $L$. perenne $\times$ multiflorum showing inflorescence with awns inherited from the paternal $L$. multiflorum parent. C. Inflorescence structure of $L$. multiflorum, showing the presence of awns on the lemmas and fruits.
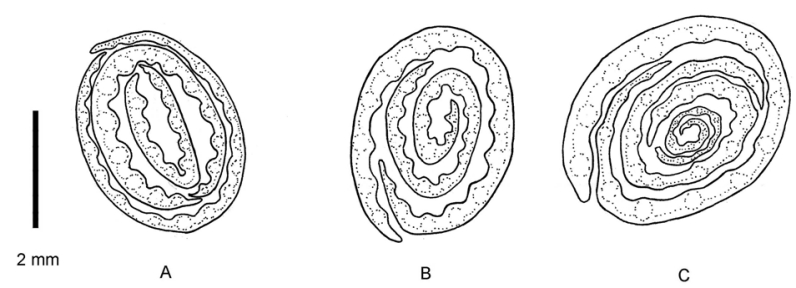

Figure 3. Inheritance of shoot characteristics in L. perenne $\times$ multiflorum hybrid crosses. A. Trans-section through shoot of Lolium perenne, showing folded leaf blades. B. Trans-section through shoot of $L$. perenne $\times$ multiflorum hybrid, showing rolled leaf blades inherited from paternal L. multiflorum parent. C. Trans-section through shoot of L. multiflorum, showing rolled leaf blades.

for example, would currently fall into this unacceptably high category of risk. Composite gene flow models thus provide us with a basis for estimating diffusion rates of novel genes into wild and non-GM crop populations that would not otherwise be available. This kind of data can only help to build public confidence in broader biosafety

Table 2. Number of L. multiflorum $\times$ L. perenne hybrids recovered from $\mathrm{F}_{1}$ progeny from pilot field study as recorded using microsatellite, inflorescence and shoot trans-section (TS) morphology markers.

\begin{tabular}{|c|c|c|c|c|c|c|c|}
\hline \multirow{3}{*}{$\begin{array}{l}\text { Plot type (number of } \\
\text { source plants) }\end{array}$} & \multirow{3}{*}{$\begin{array}{c}\text { Total number of } \mathrm{F}_{1} \\
\text { seedlings sampled from } \\
8 \text { sink plants }\end{array}$} & \multicolumn{6}{|c|}{ Number of $F_{1}$ hybrids identified } \\
\hline & & \multicolumn{2}{|c|}{$\begin{array}{c}\text { Character: } \\
\text { Microsatellite }\end{array}$} & \multicolumn{2}{|c|}{$\begin{array}{l}\text { Character: } \\
\text { Awns }\end{array}$} & \multicolumn{2}{|c|}{$\begin{array}{l}\text { Character: } \\
\text { Shoot TS }\end{array}$} \\
\hline & & No. & $\%$ & No. & $\%$ & No. & $\%$ \\
\hline 48 & 76 & 19 & $25 \%$ & 12 & $16 \%$ & 22 & $29 \%$ \\
\hline 24 & 80 & 9 & $11 \%$ & 5 & $6 \%$ & 9 & $11 \%$ \\
\hline 0 & 80 & 0 & $0 \%$ & 0 & $0 \%$ & 3 & $4 \%$ \\
\hline
\end{tabular}


$\uparrow \mathrm{N}$

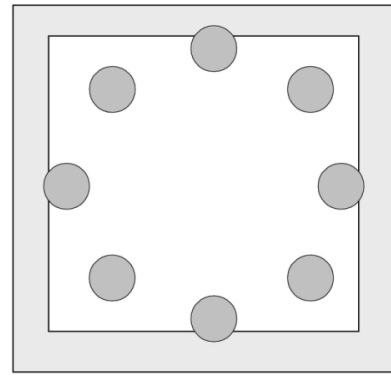

$0 / 0$

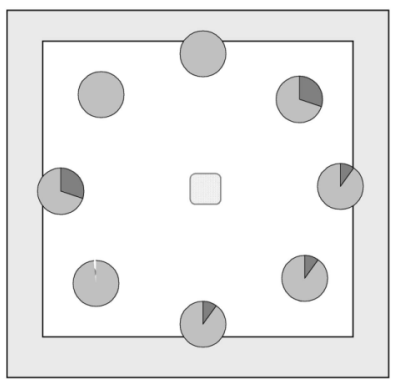

24/ 1.1

B

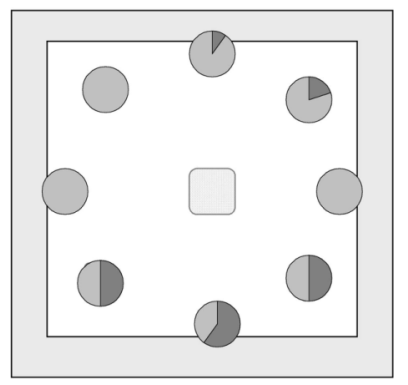

$48 / 2.5$

C

Figure 4. Results of gene flow experiment for plots containing 0 (A), 24 (B) and 48 (C) L. multiflorum Trajan pollen source plants. The frequency of $L$. multiflorum paternity in $\mathrm{F}_{1}$ seedlings from $L$. perenne Aberdart sink plants as identified using H01 H06 microsatellite alleles is indicated by shaded area in each pie chart. Figures underneath each plot indicate (i) the number of pollen source plants/(ii) the mean number of hybrids per 10 germinated $\mathrm{F}_{1}$ seedlings in that plot.

Table 3. Chi-square and Spearman rank-order tests for significance in pilot field experiment data.

\begin{tabular}{lll}
\hline \hline Test & Result & \\
\hline Difference between observed hybrid numbers in the 3 experimental plots & Significant, $p<0.05$ & Chi-square test \\
Correlation between number of source plants and number of hybrids & Significant, $p<0.05$ & Spearman rank-order test \\
Correlation between number of hybrid progeny at sink plants and wind direction & Not significant, $p>0.05 \quad$ Spearman rank-order test \\
\hline
\end{tabular}

protocols such as co-existence, particularly where public confidence in agro-biotechnology is low. It is also conceivable that public opposition in Europe to the appearance of GM components in non-cultivated populations will continue to drive biosafety policy for the medium term. Thus we need to be aware that our clients, including public, government and health and safety representatives, may for some years to come demand gene-flow as much as trait-specific data. Though the empirical momentum has recently (and quite rightly) shifted to the latter, both datasets continue to be relevant.

\section{MATERIALS AND METHODS}

\section{Selection of plant varieties for field experiment}

A number of Lolium perenne and Lolium multiflorum advanced cultivar varieties were requested from the Institute of Grassland and Ecology Research (IGER), Aberystwyth, Wales and screened as to their suitability for a field gene flow experiment. Of the sample set, L. perenne Aberdart and L. multiflorum Trajan shared a heading date (the last week of May) that was suitable for the crop cycle at the Teagasc Crop Research Centre, Oak Park, and so were selected for preliminary microsatellite analysis.

\section{Microsatellite marker screening}

A total of 16 SSR primer pairs were screened for their ability to differentiate between potential $L$. multiflorum and $L$. perenne hybrids $(L m \times L p)$ and $L$. perenne $\times L$. perenne crosses $(L p \times L p)$ (Tab. 1$)$. DNA extraction was completed as follows: leaf tissue from 10 samples each of Aberdart and Trajan was dried in silica gel and ground into a powder using a Qiagen Retsch mm300 mixer mill and genomic DNA was isolated from each sample using a Mahery Nagle Plant DNA extraction kit using the manufacturer's protocols.

Polymerase Chain Reaction amplification of microsatellite loci utilized a standard PCR gel mix from BIOTOOLS that comprised $2 \mu \mathrm{l}$ of DNA (in $100 \mu \mathrm{l}$ of Mahery Nagel elution buffer), $1.5 \mu \mathrm{l}$ of forward and reverse primer, $2 \mathrm{mM} \mathrm{MgCl} 2,1$ unit of Taq polymerase, $200 \mu \mathrm{M}$ of dNTPs, $1 \mathrm{X}$ buffer and $25 \mu$ of PCR grade $\mathrm{H}_{2} \mathrm{O}$ 
with a total reaction volume of $50 \mu \mathrm{l}$. Optimization of PCR annealing temperatures for each locus was achieved using a 50-60 ${ }^{\circ} \mathrm{C}$ 8-step gradient PCR run on an Eppendorf Gradient Thermocycler with product visualized on an ethidium bromide-stained 4\% Pronadisa agarose TAE gel run at $65 \mathrm{~V}$ for 180 minutes. Each locus was amplified in each of the 10 Aberdart and 10 Trajan samples (320 assays in total) to establish if alleles of different sizes were fixed in the two species at that locus. Primers for loci showing the desired fixation patterns were fluorescently labeled and following PCR amplification product was run on an Applied Biosystems AB310 Genetic Analyzer. Fragment peaks from each sample run were then uploaded to Genotyper $^{\mathrm{TM}}$ (Applied Biosystems) for alignment and size determination.

\section{Selection of discrete morphological traits}

An examination of Hubbard's (1984) taxonomic descriptions of Lolium species that occur in Ireland suggested the most useful taxonomic characters for differentiating between $L$. multiflorum and L. perenne are the presence of awned inflorescences and rolled shoots in L. multiflorum, versus inflorescences without awns and shoots that are folded just once in L. perenne (Hubbard, 1984) (Figs. 2 and 3). A survey of 50 plants each from the IGER L. multiflorum Trajan and L. perenne Aberdart seedlots revealed that these characters were both discrete and consistent for identifying plants to species. In addition, field surveys in summer 2001-2 throughout Ireland suggested that awns are frequently displayed by hybrids where perennial and Italian Ryegrasses co-occur. Perennial Ryegrass does also differ from Italian Ryegrass in its greater longevity (Lolium multiflorum is typically an annual plant), however in a short-term experimental scenario the use of morphological presence/absence traits provides a more time-efficient means for visual spotchecking for hybrid progeny between the two species.

\section{Pilot field hybridization study}

A pilot site was established consisting of nine $12 \times 12 \mathrm{~m}$ fallow plots each surrounded by a border of winter oats. Each of the nine plots contained 16 L. perenne Aberdart sink plants arranged in pairs on eight points of the compass at a radius of $5 \mathrm{~m}$ from the plot center (Fig. 5). At the center of each plot was the putative pollen source, consisting of 48, 24 or 0 L. multiflorum Trajan plants (Figs. 4 and 5). The plots with no pollen source plants were included to allow the measurement of any background levels of pollen moving over the site or between plots within the site. In

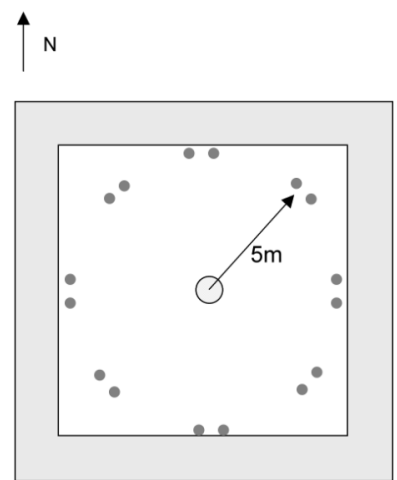

Figure 5. Layout of individual gene flow plot showing Lolium multiflorum Trajan pollen source sward at center and Lolium perenne Aberdart pollen sink plants arranged in pairs at eight points of the compass on a radius $5 \mathrm{~m}$ from the center of the source plant sward. Nine plots were established in total, three each containing 0,24 or 48 source plants with each plot separated from all others by winter oats.

addition, sink plants were planted in pairs to examine whether $L$. multiflorum pollen could complete fertilization when faced with competition from within-plot L. perenne pollen, a scenario likely to arise in natural populations. Over the course of April to August 2003 all of the trial plants were allowed to mature and flower. Seed was gathered in the $3 \mathrm{rd}$ week of August, c. 8 weeks after initial heading that had been delayed by poor weather. One each of the 0,24 and 48 source plant plots were selected at random for analysis. For each pair of Aberdart sink plants seed from three inflorescences was pooled and $36 \mathrm{~F}_{1}$ seeds were germinated at random, and a further subset of $10 \mathrm{~F}_{1}$ plants were selected at random from this pool for analysis. DNA extraction was successfully completed for a total of 236 of these $F_{1}$ progeny (Tab. 2).

Putative hybrids were first identified amongst the 236 $\mathrm{F}_{1}$ progeny of the L. perenne sink plants by spot checking for the presence of $L$. multiflorum morphological traits (awned inflorescences and a rolled basal leaf shoot in trans-section) (Tab. 2, Figs. 2 and 3). Each plant was then analyzed for the presence of L. perenne and L. multiflorum specific-alleles at the H01 H06 locus (Tab. 2, Figs. 1 and 4). A Chi-square test was carried out to determine if there was a significant difference between the observed hybrid numbers in the three experimental plots. A Spearman rank-order correlation test was also applied to determine whether there was a significant correlation between the number of source plants and the number of hybrids in each of plots. A Spearman rank-order test was also carried out to determine if there was a significant correlation between the number of hybrid progeny from 
Tracing Ryegrass hybridization using microsatellite and morphological markers

each pollen sink and the frequency of wind moving in the appropriate compass bearing between the source and sink.

Received June 29, 2006; accepted December 24, 2006.

\section{REFERENCES}

Boys J, Cherry M, Dayanandan S (2005) Microsatellite analysis reveals genetically distinct populations of red pine (Pinus resinosa, Pinaceae). Am. J. Bot. 92: 833-841

Colbach N, Clermont-Dauphin C, Meynard JM (2001) GENESYS: A model of the influence of cropping system on gene escape from herbicide tolerant rapeseed crops to rape volunteers. Agric. Ecosys. Environ. 83: 235-270

Desplanque B, Boudry P, Broomberg K, Saumitou-Laprade P, Cuguen J, Van Dijk H (1999) Genetic diversity and gene flow between wild, cultivated and weedy forms of Beta vulgaris L-(Chenopodiaceae), assessed by RFLP and microsatellite markers. Theor. Appl. Genet. 98: 1194-1201

Dow BD, Ashley MV (1998) High levels of gene flow in bur oak revealed by paternity analysis using microsatellites. $J$. Hered. 89: 62-70

Flannery M, Meade C, Mullins E (2005) Employing a composite gene flow index to numerically quantify a crop's potential for gene flow: an Irish perspective. Environ. Biosafety Res. 4: 29-43

Giddings GD, Sackville Hamilton NR, Hayward MD (1997) The release of genetically modified grasses. Part 1 . Pollen dispersal to traps in Lolium perenne. Theor. Appl. Genet. 94:1000-1006

Giddings G (2000) Modelling the spread of pollen from Lolium perenne. The implications for the release of wind-pollinated transgenics. Theor. Appl. Genet. 100: 971-974

Halsey ME, Remund KM, Davis CA, Qualls M, Eppard PJ, Berberich SA (2005) Isolation of maize from pollenmediated gene flow by time and distance. Crop Sci. 45: 21722185
Hubbard CL (1984) Grasses. A Guide to their Structure, Identification, Uses and Distribution in the British Isles. London, Penguin Books

ISB (2003) February 2003 News Report. Information Systems for Biotechnology, Virginia Tech, Blacksburg, Virginia

IGC (2005) Satellite Workshop on Genetic Improvement of Grasses and other Forage Crops. 20th International Grassland Conference, June 27th to July 7th, University College Dublin, Ireland

Jarne P, Lagoda PJL (1996) Microsatellites, from molecules to populations and back. Trends Ecol. Evol. 11: 424-429

Jones ES, Dupal MP, Kollier R, Drayton MC, Forster JW (2001) Development and characterization of simple sequence repeat (SSR) markers for perennial ryegrass (Lolium perenne L.). Theor. Appl. Genet. 102: 405-415

Kubik C, Meyer WA, Gaut BS (1999) Assessing the abundance and polymorphism of simple sequence repeats in perennial ryegrass. Crop Sci. 39: 1136-1141

McHughen A (2006) The limited value of measuring gene flow via errant pollen crom GM crops. Environ. Biosafety Res. 5: 1-2

Meade C, Mullins E (2005) GM crop cultivation in Ireland: ecological and economic considerations. Proc. R. Ir. Acad.: Biol. Environ. 105B: 33-55

Sprangenberg G, Wang Z-Y, Potrykus I (1998) Biotechnology in Forage and Turf Grass Improvement. In Frankel R et al., eds, Monographs on Theoretical and Applied Genetics 23, Berlin, Springer, pp 192

Tiedje JM, Colwell RK, Grossman YL, Hodson RE, Lenski RE, Mack RN, Regal PJ (1989) The planned introduction of genetically engineered organisms: ecological considerations and recommendations. Ecology 70: 298-315

Watrud LS, Lee EH, Fairbrother A, Burdick C, Reichman JR, Bollman M, Storm M, King G, Van de Water PK (2004) Evidence for landscape-level, pollen-mediated gene flow from genetically modified creeping bentgrass with CP4 EPSPS as a marker. Proc. Natl. Acad. Sci. USA 101: 14533-14538

Webb DA, Parnell J, Doogue D (1996) An Irish Flora. Dundalk, Dún Dealgan Press 